$\underline{\text { Article }}$

\title{
The Renewed Relevancy of High-Impact Practices (HIP): Doubling Down on our HIP Identity in Support of Responsible IB Education
}

\author{
Astrid Schmidt-King \\ 1 Loyola University Maryland, USA \\ Keywords: capstone projects, e-portfolios, integrated learning, high-impact practices, ib education \\ https://doi.org/10.46697/001c.13435
}

\section{AIB Insights}

Vol. 20, Issue 1, 2020

\begin{abstract}
While the utilization of High-Impact Practices (HIPs) in higher education is not a new phenomenon, their potential value to international business (IB) education should not be overlooked or underestimated, especially at a time when IB educators need to act strategically and demonstrate the relevancy and value-proposition of IB education in developing global leaders. This article examines the intrinsic value of IB's interdisciplinary nature and its important relationship with globalization. It then explores two HIPs, e-portfolios and phenomenon-based capstone projects, which are uniquely positioned to enhance and showcase the inherent transformative nature of IB learning and highlight its distinct pedagogical approach.
\end{abstract}

\section{INTRODUCTION}

High-Impact Practices (HIPs) are not cutting-edge and their utilization in higher education is not a new phenomenon. That said, their potential value to international business (IB) education should not be overlooked or underestimated, especially at a time when IB educators need to think and act strategically. In the current environment where the global liberal order feels less stable, protectionism is on the rise, uni- and bi-lateralism rival multilateralism, and countries are increasingly looking inward, IB educators often take a defensive posture when espousing the relevance of IB education. But defense alone is not enough at this crucial time. IB educators must also play offense and proactively showcase the importance of IB education. Deglobalization, slowbalization, and anti-globalization sentiment do not signal a time to retreat, but rather they provide IB education with a rare opportunity to showcase its relevancy as a discipline and our responsibility as educators of global leaders.

This article challenges IB educators to rethink and reassess existing resources that can be used to meet this objective. While defending the importance of IB is unavoidable at this critical juncture, playing offense provides a greater sense of ownership and it allows us to positively and proactively shape the narrative surrounding IB education. First, this article examines the intrinsic value of IB's interdisciplinary nature and its important relationship with globalization. It then explores two HIPs, e-portfolios and capstone projects, which are uniquely positioned to enhance and showcase the inherent transformative nature of IB learning and highlight its distinct pedagogical approach. The article contends that the use of e-portfolios and capstone projects, especially at this point in time, is compelling - these HIPs support educators in advancing responsible IB education and they provide tangible platforms that underscore IB education's novel value proposition.

\section{THE IMPORTANCE OF NOW: GLOBALIZATION 4.0 REQUIRES IB EDUCATION 4.0}

The theme of Davos 2019, "We're in a new economic era:
Globalization 4.0," signifies the importance of this new chapter for globalization. "The unprecedented pace of technological change means that our systems of health, transportation, communication, production, distribution, and energy - just to name a few - will be completely transformed. Managing that change will require not just new frameworks for national and multinational cooperation, but also a new model of education" (Schwab, 2018). This dynamic global environment demands that IB education be nimble, innovative, and proactive. It requires our discipline to adapt in order to ensure that our students are responsibly prepared for, and adept at, navigating the changing global landscape and it challenges us to explore the following questions:

- How can IB educators foster a cohesive and integrated transformational learning experience that prepares IB students for Globalization 4.0 and beyond?

- How can IB educators demonstrate the relevancy and value proposition of IB education?

One way to respond to these questions is to utilize tools that intentionally and explicitly leverage and highlight the strength of IB's interdisciplinary nature in our globalized world. Not a functional area, IB lives everywhere and nowhere; the infusion of "global" across functional areas can feel like the diffusion, and even dilution, of IB. However, IB educators understand that the whole of IB is far greater than the sum of its parts and we appreciate that IB's interdisciplinary nature is precisely what shapes its unique approach to integrated, transformational learning. IB's relationship with various other disciplines, both business and non-business, and its natural synergies with the multidimensional aspects of globalization, are IB's value proposition, not its handicap. HIPs, specifically e-portfolios and capstone projects, provide structures to support and showcase this value proposition.

\section{SHOWCASING IB'S VALUE PROPOSITION THROUGH HIPS}

Evidence-based research suggests that the meaningful in- 
Faculty Testimonial

"Student leaders at the University of Michigan [...] had no trouble listing activities on and on-off campus as well as courses that had been important to them. The challenge was in extracting meaning from their work and how they could best connect, indeed produce, their current goals, personal philosophy and a coherent understanding of the knowledge and skills they possessed. [...] The students who have participated in these early [e-portfolio] pilot courses have described them as 'transformative'" (Miller \& Morgaine, 2009).

\section{Student Testimonial}

"After putting up my projects in my e-portfolio, I then started to think more about my future and my career. [...] I decided to use my eportfolio as an opportunity to show and demonstrate all the skills that I have learned [...] Not only have I gained technical skills, but I've learned how to express myself as a serious student and a hard worker" (Miller \& Morgaine, 2009).

corporation of select high-impact educational practices positively impacts student participation, engagement, learning, retention and graduation rates (Sendall, Stowe, Schwartz, \& Parent, 2016). While there are numerous HIPs, the Association for American Colleges \& Universities (AAC\&U) highlights eleven:

1. first-year seminars and experiences;

2. common intellectual experiences;

3. learning communities;

4. writing-intensive courses;

5. collaborative assignments and projects;

6. undergraduate research;

7. diversity/global learning;

8. e-portfolios;

9. service learning, community-based learning;

10. internships; and

11. capstone courses and projects (Kuh, 2008).

A natural connection with IB education, AAC\&U's diversity/global learning HIP highlights the importance of "courses and programs that help students explore cultures, life experiences, and worldviews different from their own" (Kuh, 2008). With this foundational support for IB education, this article focuses on two HIPs - e-portfolios and capstone projects - as powerful tools that can be used to showcase IB's strengths and support transformational learning. Executed in an intentional, consistent manner, e-portfolios can serve as framework and support system for various other HIPs, including a capstone project.

\section{NEW APPLICATIONS OF EXISTING TOOLS: THE INTEGRATION OF E-PORTFOLIOS AND \\ CAPSTONE PROIECTS INTO IB EDUCATION}

\section{E-PORTFOLIOS: A FRAMEWORK IN SUPPORT OF INTEGRATED LEARNING}

While the undergraduate experience may include a wellrounded core, a plethora of majors and minors, and a variety of impactful co-curricular opportunities that support student engagement, we often do not provide a framework by which students can integrate, engage with, and relate these learning opportunities in meaningful ways. As institutions promote greater integration of the curriculum with study abroad, internships, service-learning, and other experiential learning opportunities, e-portfolios can serve as a valuable tool for students, faculty members, and advisors to map out, reflect on, and showcase this work.

Defined by Sutherland and Powell (2007) as a "purposeful aggregation of digital items - ideas, evidence, reflection, feedback, etc., which 'presents' a selected audience with ev- idence of a person's learning and/or ability," e-portfolios enhance, enrich, and synthesize the student learning experience. E-portfolios allow students to engage with an interdisciplinary framework as proactive participants rather than as passive observers. This not only creates student accountability, but it also challenges students to connect subjects, projects and experiences that may, on their surface, appear disparate. As a tool that nurtures personal reflection, professional development, and goal setting, e-portfolios also support the recognition of integration between various learning and life experiences, providing deeper understanding in support of a transformative educational experience.

\section{E-PORTFOLIOS: UNIQUELY SUITED TO SHOWCASE IB'S INTERDISCIPLINARY VALUE PROPOSITION}

The meaningful use of e-portfolios in IB education would support and showcase the value of IB's interdisciplinarity. The creation and maintenance of an e-portfolio would not only highlight the IB thread that runs through the functional business disciplines, but it would also challenge the student to appreciate the influence and intersection between business and non-business courses. By providing students with a tool that supports greater recognition of the interrelated nature of various disciplines and deeper reflection on experiential, internship, service learning and study abroad experiences, IB educators will help students make meaning of their cumulative experiences and foster transformational learning.

In addition, e-portfolios allow IB students to visually and effectively market their skill set and experiences in a compelling way. By showcasing their hard and soft skills, technical and non-technical skills, analytical and critical thinking skills, cultural competency and language skills through courses, presentations, group projects, papers, reflections, co-curricular activities, study abroad, service learning, internships, and case competitions, IB students will demonstrate the value, relevancy and marketability of their IB education. In addition, as illustrated in Table 2, e-portfolios are also a valuable tool for IB educators.

\section{IB CAPSTONE PROJECT: A CRITICAL COMPONENT OF A STUDENT'S E-PORTFOLIO}

The final contribution to an IB student's e-portfolio could be a capstone project in connection with a required course. IB students are uniquely positioned to complete a culminating project that highlights the global integration of core business functions (e.g., finance, economics, marketing, information systems, law, operations, accounting, etc.), non- 
Table 2: The Incorporation of E-portfolio into IB Education

Students will be able to:

Educators will be able to:

Actively plan aspects of their undergraduate education

Reflect and integrate their experiences in and out of the classroom and in and out of the country

Enhance their self-presentation and showcase their best academic work and activities for any post-graduation plans

Recognize the multi-dimensional aspects of an IB education and draw meaningful connections between courses, co-curricular and life experiences
Foster and support cross-disciplinary collaboration through assignments and experiential learning

Access these products for assessment of student learning

Provide a value-added experience that creates a formative and summative experience for IB students

Assist IB students in their personal and professional development and provide a concrete set of products to assist with post-graduation plans

Table 3: Shared Characteristics, Approaches and Dimensions

\begin{tabular}{|c|c|}
\hline IB Education & Globalization \\
\hline Comprehensive, interdependent approach & Comprehensive, interdependent phenomena \\
\hline Interdisciplinary and multidisciplinary & Multifaceted and multidimensional \\
\hline Quantitative and qualitative & Quantitative and qualitative \\
\hline Connects and integrates other disciplines and sub-disciplines & $\begin{array}{l}\text { Highlights the interrelationship and influence of various issues } \\
\text { and aspects of society (locally, nationally and globally) }\end{array}$ \\
\hline $\begin{array}{l}\text { Engages with issues related to economic, financial, political, } \\
\text { legal, social, cultural, technological, transportation and } \\
\text { movement (people, services, goods, etc.) }\end{array}$ & $\begin{array}{l}\text { Relates to issues including economic, financial, political, legal, } \\
\text { social, cultural, technological, transportation and movement } \\
\text { (people, services, goods, etc.) }\end{array}$ \\
\hline $\begin{array}{l}\text { Incorporates and examines various stakeholders, including } \\
\text { individuals, nation-states, governments, global and local } \\
\text { businesses, multinational corporations and enterprises, non- } \\
\text { governmental and intergovernmental organizations, institutions }\end{array}$ & $\begin{array}{l}\text { Engages and impacts various stakeholders, including } \\
\text { individuals, nation-states, governments, global and local } \\
\text { businesses, multinational corporations and enterprises, non- } \\
\text { governmental and intergovernmental organizations, } \\
\text { institutions }\end{array}$ \\
\hline $\begin{array}{l}\text { Examines big questions, wicked problems and long-term } \\
\text { challenges }\end{array}$ & $\begin{array}{l}\text { Presents big questions, wicked problems and long-term } \\
\text { challenges }\end{array}$ \\
\hline
\end{tabular}

business courses and co-curricular activities. Not only would an IB capstone project highlight the importance of dissecting and understanding current events from various perspectives - a skill demanded in the contemporary globalized world - it would also allow for students to engage broader social sciences, cross-cultural, and comparative studies. The project would also challenge students to conduct problem-led, integrative, engaged analysis needed to address key challenges and policy issues, and to examine the relationship between different phenomena.

Given IB education's natural connection with globalization, the capstone project could be a case study based on a real-world phenomenon. This would capitalize on the existing synergies and alignments shared by IB education and globalization, and it would allow the student to demonstrate the importance of an interdisciplinary, multidimensional approach to dynamic global issues. As highlighted in the chart below, IB students are exceptionally well-positioned to analyze a real-world phenomenon from various vantage points. This integration of learning and perspective as applied to real-world phenomena is not a skill that can be taught in one semester, rather it needs to be nurtured through intentionally designed projects like a phenomenon-based capstone project which can then be showcased in a student's e-portfolio.

While research is critical to advancing our discipline, given the current climate, it is imperative that we focus on our responsibilities beyond research. As IB educators, we are challenged to develop students who possess the skills needed to adroitly navigate an increasingly complex global landscape. While this responsibility has always been central to IB education, it has taken on new relevancy and a sense of urgency. E-portfolios and capstone projects are valuable tools that IB educators can utilize as they design a transformational learning experience. These HIPs help develop a student's ability to integrate various perspectives and insights and apply them to a given challenge or phenomenon.

\section{HIPS IN SUPPORT OF DEVELOPING IB PRACTITIONERS AND GLOBAL LEADERS}

Both e-portfolios and phenomenon-based capstone projects are HIPs that advance institutional priorities (e.g., student success, retention, graduation rates, reputation, accreditation, etc.) (Sendall et al., 2016), demonstrate IB's value proposition, showcase IB's interdisciplinary nature and the meaningful integration of curricular, co-curricular and experiential learning, support a cohesive transformational learning experience that prepares IB students, and challenge students to proactively engage in and make meaning of their learning experiences. "This power to combine disciplines and connect them across levels of analysis, from the micro-foundations of decision-making to the macro level of globalization, is needed to address today's ‘big questions"” (Collinson, 2017). 
May we use this compelling time of heightened awareness surrounding global issues and increased discussion on the state of the liberal order to strengthen our pedagogical vision for IB education and reflect upon and clarify our role and responsibility as IB educators. The future demands that we prepare students positioned to answer the big questions of today and address the wicked problems of tomorrow. Our integrated markets and shared planet challenge us to create an educational experience that is exploratory instead of explanatory and develop informed global leaders poised to succeed during Globalization 4.0 and beyond. This is not only the responsibility of IB educators, it is also the promise of an IB education and the realization of a transformational learning experience.

\section{ABOUT THE AUTHOR}

Astrid Schmidt-King (aschmidt-king@loyola.edu) is an Executive in Residence at Loyola University Maryland and the Director of the International Business Program. She earned her J.D. from the University of Baltimore School of Law, LL.M. in Law and Government from American University, and M.A. in International Relations and Global Politics from Freie University in Berlin, Germany. She teaches international business, business law, ethics and corporate social responsibility, and researches issues related to the socio-economic impacts of globalization. 


\section{REFERENCES}

Collinson, S. 2017. The Declining Relevance and Legitimacy of IB Scholarship in a World That Really Needs It. AIB Insights, 17(2): 7-10.

Kuh, G. D. 2008. High-Impact Educational Practices: What They Are, Who Has Access to Them, and Why They Matter. Association of American Colleges \& Universities. https://www.aacu.org/leap/hips.

Miller, R., \& Morgaine, W. 2009. The Benefits of Eportfolios for Students and Faculty in Their Own Words. Association of American Colleges \& Universities. https://www.aacu.org/publicationsresear ch/periodicals/benefits-e-portfolios-students-and-fac ulty-their-own-words.
Schwab, K. 2018. Globalization 4.0 - what does it mean? World Economic Forum. https://www.weforu m.org/agenda/2018/11/globalization-4-what-does-itmean-how-it-will-benefit-everyone/.

Sendall, P., Stowe, K., Schwartz, L., \& Parent, J. D. 2016. High-Impact Practices: An Analysis of Select University and Business School Programs. Business Education \& Accreditation, 8(2): 13-27.

Sutherland, S., \& Powell, A. 2007. CETIS SIG Mailing List Discussions. https://www.jiscmail.ac.uk/cgi-bin/ webadmin?A1=ind0707 \&L=CETIS-PORTFOLIO\#3. 